\title{
UPDATED NOTICE: PUBLICATIONS OF THE FOUNDATION
}

\section{1) Index of Titles and Authors in Environmental Conservation (1974-95)*}

The Index for 1974-86 (both inclusive), and its first Supplement (covering the years 1987 and 1988), are still available from the undersigned at the price (for the two, including surface postage) of US $\$ 40 \dagger$ or $60 \dagger$ Swiss francs as long as stocks last. It is anticipated that most of our subscribers, at least, will wish to possess a copy of this pioneering Index of which the first part, with its 9,399 entries occupying 159 pages in the format of the Journal alone approaches twice the basic length of one of our issues but still costs less! Moreover this price will include full payment also for a further Supplement, covering the 7 years 1989-95, which is now in advanced preparation and due to be sent free to all registered purchasers of the original Index.

Referencing, as it does, seemingly the vast majority of leading Authors and topics that emerged during the formative and subsequent years of the environmental-conservational movement or 'revolution', the Index with its Supplements should represent a valuable tool for researchers and a propitious guide for writers. This was borne out by our own experience during its original compilation, when already it proved to be a most useful work of reference, ' ... altogether constituting a unique chronicle of the environmental-conservational concerns of modern times' (according to the Foreword by the then Executive Director of the United Nations Environment Programme, Dr Mostafa K. Tolba, now President of the Foundation for Environment \& Development).

2) Full Sets and Back Numbers of Environmental Conservation

We still have a few complete sets of Environmental Conservation, from its beginning with the Spring issue of 1974 to the Winter one of 1995 , available for purchase by or for worthy 'homes'. Back numbers can usually be supplied to fill gaps at a cost of US $\$ 20^{\dagger}$ apiece (postage paid).

3) Copies of Ecosystem Theory and Application

We also have some residual copies available (at US $\$ 50^{\dagger}$ each, including postage) of Ecosystem Theory and Application, published in 1986 by John Wiley \& Sons in the President's series of Environmental Monographs \& Symposia.

4) Publication of first book of Environmental Challenges

In July 1993 the Foundation for Environmental Conservation co-published the first of its planned 'Original Paperbacks: Readers by Leaders'. Entitled Environmental Challenges: From Stockholm to Rio and Beyond, it has a Foreword by Mrs Gro Harlem Brundtland and an Introduction by its Editors, Mohammad Nazim \& Nicholas Polunin, with early chapters by Mostafa K. Tolba, Nafis Sadik, Birgitta Dahl, and Arthur H. Westing; included among later chapters are those headed by Bertil Bolin, Sandro M. Radicella, and Maurice F. Strong. The price (including postage) is US $\$ 12$ for individuals and US $\$ 20$ for institutions.

5) Plans for Further Original Paperbacks on Environmental Challenges (probably one each year)

The second of these was on the crucial theme of Population and Global Security. It was aimed primarily at offering unbiassed enlightenment to participants in the United Nations' International Conference on Population and Development, which was held in Cairo, Egypt, from 5-13 September 1994, and of it a limited 'Geneva Edition' was published in July 1994 at US $\$ 15$ for individuals or US \$25 for institutions (postage free). Edited by Nicholas Polunin \& Mohammad Nazim, it comprises 12 survey-chapters on the most pertinent topics by leading exponents starting with Dr Nafis Sadik, Secretary-General of the Cairo Conference, and ending with Sir Martin W. Holdgate, latterly Director-General of IUCN. Of it an updated (post-Cairo) World Edition, with additional chapters on population prospects and foreseeable ecodisasters, is in preparation, commissioned by Cambridge University Press. In addition the Editors of these inexpensive Original Paperbacks have made a list of some 50 ideas for due consideration for further such books provided sufficient wherewithal materializes, there being no shortage of appropriate and often eager Authors.

\section{6) Proceedings of our Fourth International Conference on Environmental Future (ICEF)}

Surviving With The Biosphere was published in December 1993 by Edinburgh University Press, 22 George Square, Edinburgh EH8 9LF, Scotland, UK, at $£ 85$ hardbound. Edited by Nicholas Polunin \& Sir John Burnett, 'This volume [of about 600 pages with numerous illustrations] details the urgent global action required to preserve' Mankind and Nature's all-too-fragile only habitat, The Biosphere, based on the presented contributions and lively discussions of a galaxy of leading conservationists at the Foundation's Budapest Conference.

\section{7) World Who Is Who and Does What in Emironment \& Conservation}

Now styled as above, and with major Appendixes (I) indicating by Nation who does what of pertinence in already 125 of the world's different countries, and (II) who is concerned with each of the very numerous specialities involved, and where and how they can be contacted, this long-planned compilation of the Foundation for Environmental Conservation has latterly advanced apace. The first edition, containing about 1,300 detailed biographies, is now largely in press and expected to be published in the Autumn of 1996 - to be followed by two further cumulative editions at probably two-three years' intervals. The entire work is expected to deal with at least 3,000 of the world's most eminent and/or active living men and women in its all-important duality of subjects.

\author{
(Mrs) Lynn M. Curme, Compiler \\ Foundation for Environmental Conservation \\ 7 Chemin Taverney (7th and 8th floors) \\ 1218 Grand-Saconnex \\ Geneva, Switzerland: \\ Tel. $(++4122) 7982383$ and 4 \\ Fax $(++4122) 7982344$.
}

* Since when Environmental Conservation is being published by Cambridge University Press (Cambridge, England, and New York, NY) though continuing to be owned and administered by the Foundation for Environmental Conservation.

$\dagger$ New prices in deference to increased postal rates and inflation. 